\title{
How Political Parties Finance Electoral Campaigning in Southern Africa
}

\author{
By \\ Tom Lodge \\ Professor Tom Lodge is the Head of the Department of Political Studies at the University of the \\ Witwatersrand, Private Bag 3, Wits, 2050, South Africa; \\ Tel: +27 11717 4963; Fax: +27 11403 7482; e-mail 064tom@muse.wits.ac.za
}

\section{Introduction}

Political party electioneering finance is a subject which deserves more consideration than it receives in Africa. Efficiently and expensively administered elections in which at most only one party can afford the costs of an effective and sophisticated campaign represent a very partial fulfilment of democratisation, yet such contests are normal in the region. As well as providing useful insights in any assessment of electoral equity, examining the how parties finance their operations often helps to illuminate broader questions concerning the ways in which they attempt to build support. Free and fair elections require strong parties as much as they need efficient administrators, yet in Southern Africa Development Community (SADC) countries, as is generally the case further afield, legitimate public expenditure is predominantly concentrated on electoral bureaucracies: parties are supposed to fend for themselves. In this paper we will first consider some of the ways in which parties try to finance their operations before turning to the second question of how they spend the money they raise or use the resources they succeed in obtaining.

\section{Funding Sources}

Though the mixture varies across the different countries in the region, in southern Africa political parties fund their electioneering from five main sources. These are, in order of importance, their own governments, foreign donors, business, political party's own business operations, and finally, and probably the least important proportionately, their membership and mass support.

Public funding of political parties has become a common feature of new democracies. Though it may remove the incentive for parties 'to establish a more structural relationship with civil society'1 it probably represents a crucial resource in countries in which the modern economy has historically been under state control or in which ownership is highly concentrated and in which, therefore, corporate donations are likely to flow mainly to the incumbent party. With respect to public resources, in several countries in the SADC region there exist formal provisions for state funding or other kinds of resources which are made available to political parties during elections. Public party finance underwrites electioneering in Malawi, Mozambique, Namibia, Seychelles (constitutionally stipulated, and with relatively the most generous provisions in the region), South Africa, Tanzania, Zimbabwe, and, at least in theory, Angola. I will refer to only some of these in any detail. In Mozambique, public money for parties is administered and distributed by the electoral commission. The principle underlying 
its distribution is equitable, depending on the number of candidates put up by each party. The two main parties, Frente de Libertação de Moçambique (Frelimo) and Resistência Nacional de Moçambique (Renamo), received equal allocations, each about a third of the total. The state also pays for allocations of free broadcast time to the contestants. Since 1994 the Mozambican parties have drawn upon a US\$17 million UN trust fund administered by the commission established to promote democracy. For the ruling party, Frelimo and its adversary, Renamo, state allocations are important contributions to their campaign chests but, at least in the case of Frelimo, are more than matched by their support from other sources. ${ }^{2}$ Namibian public funding is distributed to parties which already enjoy parliamentary representation and it is sustained between elections to enable parties to maintain local offices and staff. Allocations are based on the parties' respective shares of parliamentary representation. Apportionment of free broadcast time also favours incumbent and larger parties though a threshold principle allows all contesting parties a minimum period of broadcast time. In Namibia, at least for the more established opposition parties, state funding represents a major resource.

South African public funds are distributed to political parties on much the same basis as in Namibia, with the largest allocation in 1999 of R30 million (out of a total of R52 million) going to the African National Congress (ANC). It represents a minor share of the total sums spent by all parties on electioneering though it was probably the major source for some of the smaller parties represented in parliament such as the Pan-Africanist Congress (PAC), which received R888 000. In 1994 funding was distributed to all parties which registered for the election, provided they could indicate a degree of support which would give them a realistic prospect of winning a seat: 10000 signatures (3 000 if they were only contesting a provincial legislature) or at least a 2\% showing in an opinion poll. In 1994 state funding for South African parties totalled R69 million; in the election that year estimates for ANC expenditure alone ranged between R160 million and R400 million. ${ }^{3}$

In Zimbabwe, public money for political parties is provided annually, but only to parties with a minimum parliamentary representation or 15 seats. In effect, this means that the ruling Zimbabwe African National Union-Patriotic Front (Zanu-PF) is the sole beneficiary of the Political Parties Finance Act, receiving for its 1995 campaign $Z \$ 32$ million in addition to another Z\$62 million dispensed that year to Zanu-PF controlled cooperatives by the Ministry of National Affairs, Employment Creation and Cooperatives. ${ }^{4}$ The annual state grant through the Political Parties Finance Act is believed to be five times the sum raised by the ruling party from private sources; in 1999 Zanu-PF received US\$1.53 million. ${ }^{5}$ In Tanzania state funding is more equitable. Each party that registers for electoral campaigning receives 1 million shillings for every candidate nomination and a further million for each constituency won. ${ }^{6}$

Official cash grants and allocations of public broadcasting time do not represent the limit of state support for political parties for many ruling parties in the region derive indirect

Roger Southall and Geoffrey Wood, 'Political Party Funding in southern Africa', in Peter Burnell and Alan Ware (eds), Funding Democratization, Manchester University Press, Manchester, 1998, pp209-210

The upper estimate is in Southall and Woods, op cit, pp210-225. The authors arrived at this total by adding up the likely costs of press advertising and rallies. The figure seems very high: the ANC's original campaign budget was R168 million, The Star, 6 November 1993

4 John M W Makumbe and Daniel Compagnon, Behind the Smokescreen: The Politics of Zimbabwe's 1995 General Elections, University of Zimbabwe Publications, Harare, 2000, p171

$5 \quad$ Sunday Independent, 17 October 1999

6 Magnus Ohman, Public Funding of Political Parties in Africa, International Foundation for Electoral Systems, New York, July 1999, p13 
resources for their electioneering as a consequence of incumbency. Government owned or publicly funded media are particularly vulnerable to abuse by ruling parties during election seasons, especially when no institutional devices are set in place to safeguard their independence from the executive. This danger is well illustrated by comparative South African experience during the 1994 and 1999 elections. In 1994, the impartiality of the public broadcaster was intended to be protected by the Transitional Executive Council and there was general acceptance that the South African Broadcasting Corporation (SABC) had provided fair and accurate coverage. In 1999, ensuring the broadcaster's non-partisanship was one of the responsibilities of the Independent Broadcasting Authority (IBA), a much weaker body, chaired by a prominent ANC personality. The IBA adopted an essentially passive mode of undertaking this function, responding only to complaints submitted through a formal process: it discovered little evidence of deliberate bias by the broadcaster. The Media Monitoring Project, on the other hand, while conceding that coverage of different parties was proportionately equitable, maintained that stories about the ruling parties tended to be favourable whereas opposition parties were often treated disparagingly. In South Africa, complaints about incumbents' use of public resources for electioneering included the unpaid use of government transport for canvassing and transporting party leaders to rallies, the publication and mass distribution of government propaganda by the state communication agency shortly before the electoral proclamation, and the politicising of government redistributive programmes, such as land restitution grants during the months preceding the election. As one astute commentator noted in May 1999:

The processing of land claims and restitution has been proceeding at a snail's pace but have now suddenly started happening at an increased rate. For five years they have been just about stalled and yet last weekend Mr Mbeki was able to hand out compensation cheques to those who suffered from forced removals in the 1960s. Of course it is simply coincidence that these cases are finalised two weeks before the election and similarly, it is just coincidence that they happen to be in ... the highly contested Western Cape, where the ANC is desperate to unseat the National Party. ${ }^{7}$

Other examples of such practices can be cited from elsewhere in the region: in Namibia in 1999, the South West Africa People's Organisation (Swapo) was the subject of opposition complaints about the appearance of army helicopters and other kinds of official transport at rallies - in a huge country in which the electorate is so widely dispersed the ruling party's access to aircraft represented an immense advantage. Swapo spokespersons argued that the party paid for such facilities but the rates cited were well below commercial costs. During the Zimbabwean election of 1995, the deployment of government patronage or threats of its withdrawal were staple items in Zanu-PF electioneering in rural areas. In March 1995, for instance, during the campaign, the Minister of Land, Agriculture and Water Development warned those in attendance at a meeting in Chipinge that 'there will be no development in their area if they continue to vote for opposition parties'. In Zimbabwe as well, in 1995, Zanu-PF admitted that researchers employed at the Ministry of Information drafted its election manifesto and other kinds of publicity used by candidates. Ruling party politicians were similarly candid about the free use of government vehicles to transport supporters to rallies. ${ }^{8}$

The advantages of incumbency are also telling in efforts to attract foreign donations. Namibia's electoral law requires parties to disclose the source of foreign funding, one of the 
very few legal provisions for disclosure existing in the region. In 1989 foreign funding was major factor in the Namibian election: the ruling Democratic Turnhalle Alliance (DTA) received at least US\$20 million from the South African government, whereas in the case of Swapo its estimated US\$18.5 million campaign expenditure was largely foreign donations, from friendly government and the international anti-apartheid movement. Both parties still maintain a national network of offices and other kinds of freehold property bought with these funds and Swapo also purchased a number of companies. In the next two elections, however, there were no disclosures of foreign donations. In Mozambique in 1994, foreign funding was needed to induce Renamo to participate in the poll (and accept the results): for this purpose US\$1 1 million was donated by Italy, the United States, South Africa and Namibia. ${ }^{9}$

In South Africa the ANC too has been the beneficiary of international anti-apartheid sentiment which also enabled the accumulation of a substantial property portfolio. More important, in the long term, though, have been the donations from governments not especially conspicuous in the anti-apartheid era, which through gifts to the ANC have sought to influence government foreign policy. Governments which have had a measure of success in such endeavours include those of Taiwan, Malaysia, Indonesia, various Arabian states, and, possibly, Nigeria. ${ }^{10}$ The Dutch government, a historical patron of the ANC, donated R18-35 million in 1995 for capacity building and councillor training by the six main parties contesting the local government elections; the ANC received the largest allocation, R1 1 million. ${ }^{11}$ Since 1994, the Inkatha Freedom Party (IFP) has received money from conservative British business people, and this generosity too has not been disinterested with both John Aspinall and James Goldsmith involved in KwaZulu-Natal casino licence bids. The Democratic Party (DP) is reputed to receive money from the Naumann Trust, a German political foundation which also supports the Helen Suzman Foundation, a research body closely linked to the DP. In Botswana in 1999, a large grant of US\$500 000 to the ruling Botswana Democratic Party (BDP) by the De Beers diamond corporation angered opposition parties. Though perfectly legal, such largesse is utterly disproportionate to the sums which can be raised from local private sector sources. As with the ANC, foreign funding may have accounted for a major share of the expenditure in the BDP's 1999 electioneering. Zanu-PF's 1995 electoral budget was augmented by a Z\$14 million donation from Lonrho as well as Z\$7 millions' worth of equipment from China.

Generally individual donations to political parties from the local business community are on a smaller scale compared to this transnational munificence. Even so, Frelimo in 1999 apparently managed to find sufficient numbers of allies within the Maputo business community to raise US\$700 000 from political dinner parties. ${ }^{12}$ In South Africa, the National Party (NP) has traditionally relied on funding from Afrikaner business though at least one important former backer, the insurance giant Sanlam, has switched its support to the ruling party. A statement

Southall and Wood, op cit, p209

Advisers to Nigeria's ruler, General Sani Abacha, told journalists that Abacha had contributed US $\$ 5$ million to the ANC's election expenses in 1994. The assertion was denied by an ANC spokesperson (Sunday Independent, 14 July 1996). Greg Mills, director of the South African Institute of International Affairs suggested that during the 1990's foreign donations to the ANC from 'questionable sources' totalled R1.12 billion (Eastern Province Herald, 31 May 1999). In 1999, Nelson Mandela told a meeting in Lenasia that in 1998 the rulers of both Saudi Arabia and the United Arab Emirates had each contributed US $\$ 10$ million to the ANC's treasury (Southern African Report, 23 April 1999). The Star, 28 November 1995

Lloyd Sachikonye, 'The functioning and funding of political parties in the SADC region', paper presented at the International IDEA conference on Sustainable Democratic Institutions in Southern Africa, Gaberone, 8-10 May 2000, p17. See also endnote 19. These look like they are in a (possibly published) collection (page numbers). 
by the ANC treasurer at its 1997 conference suggested that R500 000 was the minimum donation it was going to solicit from members of the recently empowered 'patriotic bourgeoisie'. The DP is at present engaged in a fundraising drive for the local elections: telephone calls to select individuals are reportedly netting about R1 million a day ${ }^{13}$ In the past about $80 \%$ of DP donations have come from individual standing orders. In the 1999 elections the DP's R20 million expenditure was mainly derived from private sources; the party only received R1.7 million's worth of public funding whereas in the previous general election public funds constituted $80 \%$ of their finance. ${ }^{14}$ At the time of their merger in mid 2000 the DP was competing fiercely with the NP for the patronage of Afrikaner capital and had obtained money from Nasional Pers, traditionally a financial bastion of Afrikaner nationalism. The IFP benefits from a long traditional of sponsorship by Natal sugar groups and its benefactors also include illegal casino operators in the region who donated R100 000 in 1998. Newspaper speculation about the political influence of the gambling industry intensified when Chief Mangosuthu Buthelezi was observed converting R1 million into a cheque made out to the IFP at his Ulundi bank. ${ }^{15}$ Inkatha is certainly not the only South African political party which has been accused of receiving money in exchange for favours. In Mpumalanga, the secret Dolphin Group purchase of development rights over provincial parkland was accompanied by a R105000 donation to the ANC Youth League from the Mpumalanga Parks Board, one of the participants in the sale. ${ }^{16}$ Interestingly, one of the defence ploys used by the former (NP) minister for social security, Abe Williams, when he was put on trial for accepting bribes to ensure that electronic equipment was supplied by a particular company was that 'the money was donated to (his) 1994 election campaign and did not constitute bribery'. ${ }^{17}$ That such an argument could commend itself to Williams' lawyers is itself a telling reflection on the ethical confusion which prevails in South Africa on political party funding.

In Namibia, the Congress of Democrats (CoD) has apparently displaced the DTA as the opposition party of choice among local business people though the individual amounts received in 1999 did not exceed N\$100 000. Only in South Africa and Namibia does the local business community make a substantial contribution to the sustenance of opposition politics; elsewhere business support mainly consolidates ruling party supremacy.

In South Africa, the ANC's efforts to establish its own business enterprises have been generally disappointing. The NP continues to benefit from trust funds it established after its formation in 1912. In Namibia and Zimbabwe party business is big business. In Namibia Swapo owns a bus company, a freight enterprise and a printing works, each of them the largest and most sophisticated in their fields. Swapo's printing company was responsible for the production of ballot papers in 1998 and 1999, securing the contract through competitive tender procedures. Zimbabwe's Zanu-PF's business interests include the MES Syndicate which invests in companies are involved in vehicles sales, garages, property, machinery imports and mining equipment. In 1990, a company brochure suggested that the syndicate was making Z\$390 million a year. Until 1998 the ruling party also owned half the shares in Woolworths, Catercraft (the operating company for Harare's airport) and National Blankets. ${ }^{18}$ Its other commercial affiliates hold government contracts for text book supplies and defence

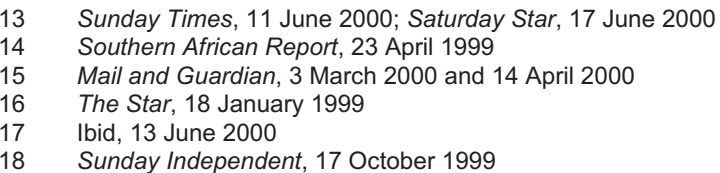


materials. Meanwhile, the Botswana Democratic Party (BDP) conducts business on a more modest scale, renting out office space to government departments. In Mozambique, Frelimo, at least until recently, earned money from party-owned companies and Renamo reputedly earns an income from concession granting in regions in which it hold local authority.

Membership and affiliate support is relatively more important as a resource for parties in the poorer countries in the region. It provides the main kind of finance for opposition parties in Zambia which rely heavily on membership card sales. ${ }^{19}$ These at best represent a precarious source of income: the United National Independence Party (UNIP) in 1998 did not have enough money to settle a K2.4 million lawyer's bill. The ruling Movement for Multi-party Democracy (MMD) at its inception depended on contributions from trade unionists but today derives greater benefits from 'macing', that is the coercion of contributions from contractors and supplicants for government attention. Even so, the MMD was reportedly bankrupt at the beginning of 1999 with debts in excess of K200 million. ${ }^{20}$ In South Africa, the ANC's R12 annual membership fee is mostly unpaid; in 1999 the R1 million donation from its trade union ally the Congress of South African Trade Unions (Cosatu) was symbolically important but hardly represented a major contribution. Nor is the levy on parliamentarians' salaries very decisive: annually this brings in about R3 million, apparently. ${ }^{21}$ Generally, in South Africa, as elsewhere, the smaller parties depend most extensively on their members: this is the case especially with the African Christian Democratic Party which, appropriately enough, tithes its supporters and runs its campaigning mainly through volunteers.

\section{Expenditure}

No SADC country compels political parties to conform to rigorous disclosure laws and any limits on campaigning expenditure are exceptional. Zimbabwe, it is true, does restrict individual candidate expenditure and, officially, at least, subjects this to quite tight accounting procedures, but this is not matched by any comparable measures to open up central party funding to public scrutiny. ${ }^{22}$ Similarly, Botswana and Mauritius limit individual candidate expenditure but allow parties to spend as much as they can. State funding is also usually controlled through reporting rules although these are often administered lightly. As we have seen, however, most electioneering expenses are paid for through private donations and here disclosure requirements are exceptional. Assessing how parties spend their money has to involve informed speculation rather than precise accounting. In South Africa, the high cost of press advertising (R250 000 for a full page of a Sunday newspaper) indicates a majority of expenditures by the main parties was on press notices though there were noticeably fewer of these in 1999 than in 1994. In South Africa the three main parties in 1999 also invested heavily in radio commercials over and beyond their free air time - the DP, for example spent R4 million on radio publicity; party television advertising however remained prohibited. South African parties also commissioned national surveys from market research agencies; here too presented at International IDEA's Conference on Sustainable Democratic Institutions in Southern Africa, Gaberone, 8-10 May 2000, p179

20 Laurent Kaela, Zambian Electoral Audit, Electoral Institute of Southern Africa, Johannesburg, March 1999, pp10-11

21 Sunday Times, 14 May 2000

22 The head of Zanu-PF's finance department, Emmerson Mngangwa, claims that the party's accounts were privately audited and that the statements were available to central committee members, but provincial leaders, members of the central committee denied seeing any such documentation (Sunday Independent, 17 October 2000). 
the bills can run into millions. Massive expenditure on posters with saturation coverage of public space by placards and bill boards distinguish South African elections from most of their counterparts in the region where resources commanded by even ruling parties are comparatively more modest. All these undertakings reflected a healthy commitment to the power of relatively reasoned persuasion as well as the realisation amongst parties that their electoral goals depended upon conversion of uncertain or uninterested voters. Leadership road shows and carnival like rallies represented another important commitment for party expenditure, though generally South African organisations spend smaller proportions of their budgets on events which involve direct contact between politicians and potential supporters than other parties in SADC countries, in which newspaper readership and broadcasting are less influential or open to influence. Canvassing by activists remains important in rural areas and townships but this draws heavily on voluntary time, not money.

In contrast, it is likely that in most SADC countries, the chief electioneering expenses relate to transport, hire of equipment and hand bill printing. Even in relatively affluent Namibia, street postering was inconspicuous in the 1999 election, political party advertising in newspapers was very limited, and only Swapo could afford mass distribution of a professionally produced colour printed manifesto. Direct contact through rallies, meetings and branch building were the crucial dimensions of electioneering. Facilities at party offices were simple: in Katima Mulilo, for example, a key region for the Swapo campaign, the party office in 1999 had no computer and when I visited it one day before polling, no party-owned vehicle. At its best such limitations can impose upon parties the requirement to maintain active contact with their membership, reinforcing a kind of popular accountability but the dependence on activism can also degenerate into crude forms of coercion. Zimbabwe's experience in 2000 is illustrative. Despite setting an initial fundraising target of US\$1.92 million, ${ }^{23}$ by the eve of the election campaign only $Z \$ 5$ million was available for each of the ten provincial executives for electioneering and another $\mathbf{Z} \$ 20$ million was given to the War Veterans' Association to finance its land seizures. ${ }^{24}$ In contrast to West Africa, though, allegations of vote buying are rare in the region, though it did occur apparently in Malawi in 1999 where the United Democratic Front (UDF) was accused of handing out cash at its rallies.

Whether disparities in levels of expenditure are reflected in electoral outcomes is a contested issue. ${ }^{25}$ Academic analysis has emphasised the experience of advanced industrial democracies in which all major contestants enjoy access to substantial resources and in which electioneering increasingly depends upon very expensive forms of media communication as well as direct mailing. In southern Africa volunteers or unpaid party activists still play a major role in mobilising electoral support and can sometimes compensate for financial disparities between parties. Even so, successful emergent parties probably require at least indirect access to resources. In the two major swings against an incumbent party (Zambia in 1990 and Zimbabwe in 1999) trade union support for the opposition supplied a crucial organisational underpinning for campaigning. In the case of South Africa in which political party expenditure is vastly in excess of the sums available to parties in other SADC countries, it is certainly questionable as to whether cash converts proportionately into votes. In 1994 a major proportion of the ANC's spending was on press advertising, directed chiefly at middle class

For a useful commentary on the debate see Justin Fisher, 'Party expenditure and electoral prospects: a national level analysis of Britain', Electoral Studies 18, 1999, pp519-532 
white newspaper readers, few of whom responded positively. But parties without a certain minimal level of funding have no realistic prospects unless, as with the South African Christian Democrats, they can depend upon pre-existing social networks amongst relatively affluent communities. Money is needed for 'road shows' (the chief focus of southern African electioneering), candidate registration, polling research, placards, and, increasingly, radio advertising. Only in South Africa, Seychelles and Mozambique are available public resources sufficient to allow the main contenders to run fully developed campaigns. For most opposition parties and certain ruling parties in the region private-sector sources of support are rarely available on a scale to meet the costs of sophisticated electioneering.

\section{Policy prescriptions}

Several policy conclusions arise from this very brief survey.

Firstly, more stringent disclosure requirements are probably desirable although they may need to be administered in such a way as to prevent inhibiting donations to opposition parties. This is an area where an agency such as the South African Public Protector could play a useful role in maintaining a confidential register of donations and ensuring that donor generosity is not improperly reciprocated by government. In several countries the reported scale of donations is sufficient to threaten the integrity of the ways in which governments do business with the commercial sector and in South Africa at least it is possible to trace the impact of election donations on certain policy decisions, most notably with respect to diplomatic recognition. In the last five years, South Africa has also experienced three major political scandals which have featured unregulated party donations. Disclosure is favoured by the South African Independent Electoral Commission ${ }^{26}$ and most opposition parties, but opposed by the ANC and Inkatha. ${ }^{27}$

Secondly, some kind of limits to donations would be sensible. Restricting foreign donations or directing them as in the case of Mozambique to a public fund which can support parties equitably seems a basic requirement of democracy in that contesting parties should represent national interests rather than transnational preoccupations. Foreign donations may also raise electoral expenditure to unsustainable levels as well as diminish the importance to parties of voluntarism and activism, both crucial in nurturing the internal democratic life of political organisations. Limits on domestic private sector support can also be justified with reference to the same sorts of reasons but in addition are especially important in countries in which other sectors of civil society can wield so little financial influence. In advanced industrial countries trade unions can still rival the financial support supplied by business to politicians; even in South Africa, trade union resources play a marginal role in funding electioneering.

Finally, at least with respect to public funding, a degree of equity between parties should be the main principle of distribution, at least for that proportion of the funding which is reserved for electoral expenditure. Public funds should be deployed in the public interest and in supporting party electioneering, public finance should be used to promote multi-party democracy: it is difficult to see how such an objective can be achieved if public funding is used merely to supplement the advantages of incumbency. 